\title{
The Cost and Profit of Fennel Production: A Case Study of Burdur Province of Turkey
}

\author{
Mevlüt GÜL*, Halil PARLAK, and Huriye ÖKTEM
}

\begin{abstract}
The aim of this study was to put forth production cost and profitability of enterprises engaged in fennel production in Burdur and develop suggestions in this regard. Data was obtained from 81 farmers with stratified sampling and survey methods. Fennel production area in the farms constitutes $48.2 \%$ of the total farm area and approximately half of the total gross production value of farms was obtained from fennel production. The price formation of fennel occurs in free market conditions so the change in prices will affect the incomes of the producers significantly. In order to decrease price fluctuations, marketing structure and conditions should be improved and farmers' unions can be established and contract farming should be increased.
\end{abstract}

Keywords - Fennel, profit, production cost, yield, Turkey.

\section{INTRODUCTION}

Today, medicinal and aromatic plants are one of the important points that are widely focused. Turkey has different climate types and is the favourite country in Europe with almost 11.000 plant types. Turkey flora is also rich in terms of medical plants. Its ecology is appropriate for growing these plants. 3000 of these plants are aromatic plants [1].

In addition to being the gene centre of many plants Turkey contains geographical regions in which there are certain endemic species. One of the most important regions is the Lakes Region.

Burdur located in the Lakes Region is a very rich region where over 500 endemic taxa grow floristically although its surface area is small. Thanks to being located in the West Pass Zone where characteristic features of Mediterranean and Continental climates are observed, having various microclimate regions and its diversity in terms of topography structure the province is also rich in terms of medical and aromatic plants. The province is one of the most important regions where medical and aromatic plants are widely known, used and grown in Turkey.

The homeland of fennel is West Asia and Mediterranean countries [2]. This plant has two sub-species. The one which is generally cultivated is the sweet fennel (Foeniculum vulgare Mill. var. Dulce) [3; 4]. Fennel which is cultivated in many places in the world is naturally found in the north, south and west regions of Turkey but its cultivated area is limited. The large part of the fennel seed produced is consumed in the market and the rest of it is exported [5].

M.Gül is with Süleyman Demirel University Faculty of Agriculture, Department of Agricultural Economics, 32260 Isparta, Turkey.

H. Parlak and H. Öktem were with Süleyman Demirel University, Turkey. They are Master Science students of Agricultural Economics.
It is of Mediterranean origin and herbaceous plant. Its height is $1-2 \mathrm{~m}$. its shape is like thread and its leaves consist of several pieces. Its flowers are small and yellow. It contains fixed oil and volatile oil. This plant has many effects such as facilitating digestion, depressant, removing heart throb, increasing milk in mothers, removing abdominal pain in children and enhancing eyes with the volatile oil it contains. Fresh stalks and leaves of the plant are used in fish meals and also consumed as vegetable. Its fruit is used in the production of raki instead of anise in some regions [6;7].

Cultivation areas of fennel in Burdur are very limited. There is not detailed information or data in the relevant official organizations regarding fennel production. In interviews made with the Food, Agriculture and Livestock Province and District Governorates in the region, it was stated that fennel production is important for farmers of the region in terms of providing an alternative income source. Therefore, increasing the incomes of the individuals in rural areas is an important issue in terms of rural development.

By taking into consideration the points mentioned above the aim of the study was putting forth the cost and profitability of fennel production and taking the necessary steps in this regard.

With this study literature deficit regarding the product will be removed to some extent by identifying technical, economic situations and problems in fennel cultivation on enterprise level. As a matter of fact, studies carried out on fennel regarding economy are relatively insufficient.

\section{MATERIAL AND METHODS}

In the study, Tefenni, Çavdır, Gölhisar and Karamanlı districts were chosen as target group in line with the statistical data of Burdur Province Agriculture Directorate by considering the total fennel cultivation area criterion. In these counties fennel production is intensively made. Therefore, the information obtained from 81 producers engaging in fennel production activities in the region constitutes the data of the study. The data includes 2013 production season.

In the study, cultivation area data set was formed from Farmer Register System records on producer level. All enterprises engaging in fennel production made in Tefenni, Çavdır, Gölhisar and Karamanlı were included in the population. Frequency distribution of fennel cultivation areas was performed and frequency polygon was drawn. With the help of frequency polygon population was divided into three layers by taking fennel cultivation area into consideration (layer I, layer II and layer III cover $0.10-1.50$ hectare, 1.51-4.99 hectare and 5.00 hectare and upper respectively).

Sample size random layer sampling method was applied to 
this population with $90 \%$ confidence interval and $5 \%$ error margin and it was calculated as 81 enterprises. The distribution of the sample enterprises according to the layers was performed with "Neyman Method". According to this, interviews were made with 30 enterprises from layer I, 23 from layer II and 28 from layer III (Table 1). In line with the sample width calculated, enterprises were chosen from the main group randomly. $37 \%$ of the fennel producers belong to group I, $28.4 \%$ of them to group II and $34.6 \%$ of them to group III (Table 1).

Within the scope of the determined sample information from the fennel producers was obtained with questionnaire method or face to face interview technique.

For calculating the production cost of enterprises making fennel cultivation single product budget analysis method was used. Therefore, income and expense situation was only calculated for the fennel in question not for all products cultivated in an agricultural enterprise. Since this analysis was used in the research unit machine rent prices were taken into consideration in case that producers use their own machines. Labour and bollard pull amounts used in fennel production activity were given as hour. Foreign labour fees were taken into account in the calculation of family labour fee equivalent. Pesticide amount, effective substance and fertilizer amount used in fennel production were given as the total of plant nutrients. $3 \%$ of the total variable costs constitute the general administration expenses. Working capital interest is a variable cost and refers to the opportunity cost of the capital invested in production activity. Working capital interest was calculated by applying the half (5\%) of interest rates applied by the Agricultural Bank of the Turkish Republic (Ziraat Bank) on vegetable production credits to the variable cost elements [8]. The statements of the producers in return for land rent were taken into consideration. The multiplication of the sale prices and product amount obtained from fennel production activities constitutes gross production value (GPV).

TABLE 1: THE DISTRIBUTION OF THE INTERVIEWED FARMERS OF FENNEL

\begin{tabular}{lcc}
\hline \hline Farms groups (ha) & $\mathrm{N}$ & $\%$ \\
\hline \hline I $(0.10-1.50 \mathrm{ha})$ & 30 & 37.0 \\
II $(1.51-4.99 \mathrm{ha})$ & 23 & 28.4 \\
III $(5.00 \mathrm{ha}+)$ & 28 & 34.6 \\
\hline \hline Total & 81 & 100.0 \\
\hline \hline
\end{tabular}

Gross profit was obtained by subtracting variable costs from GPV and absolute profit was calculated by subtracting total production costs from GPV. Relative profit (proportional) was obtained by proportioning GPV to the total production costs. The results of the research were given in tables and graphs and they were evaluated.

\section{RESUlTS AND DISCUSSION}

Some economic and social situations of fennel producer enterprises were given in Table 2. According to these data, the age of interviewed farms managers was 58.7 years, education level was 6.4 years and average population of farms was 3.3 heads.

Duration of experience of farms in fennel production was 20.6 years. $80.7 \%$ of farms land was owned land, $17.5 \%$ of it was rented land and $1.8 \%$ of it was shared land. $76.8 \%$ of the land owned in enterprises can be irrigated. Fennel cultivation land constitutes $48.2 \%$ of the total enterprise lands.

Fennel production value constitutes $61 \%$ of gross production values of the interviewed farms. $94.1 \%$ of farms incomes were obtained from agricultural activities.

Education levels of farmers were higher in group I farmers (6.5 years). In these farms belonging to this group the rates of rented land $(33.5 \%)$ and non-irrigated land $(28.2 \%)$ were higher. In group II farms the rate of shared land (4.6\%) was detected as higher. In group III farms it was determined that the age of the farmer (61.3 years), population of farms (3.5 heads), his experience in fennel production (21.8years), owned land rate $(93.0 \%)$, irrigated land rate $(79.9 \%)$, the share of fennel land in total land $(69.8 \%)$, the share of fennel in total gross production value $(84.7 \%)$ and the rate of agricultural production value in total income $(95.0 \%)$ were higher (Table2).

TABLE 2: SOME SOCIAL-ECONOMIC INDICATOR IN FENNEL PRODUCTION

\begin{tabular}{lrrrr}
\hline \multirow{2}{*}{ Indicator } & \multicolumn{3}{c}{ Groups of farms } & \multirow{2}{*}{ Average } \\
\cline { 2 - 4 } & \multicolumn{1}{c}{ I } & \multicolumn{1}{c}{ II } & \multicolumn{1}{c}{ III } & \\
\hline \hline Farmers age (year) & 58.6 & 55.6 & 61.3 & 58.7 \\
Farmers education level (year) & 6.5 & 6.3 & 6.3 & 6.4 \\
Population of enterprises (head) & 3.2 & 3.1 & 3.5 & 3.3 \\
Farmers experience on fennel & 20.6 & 19.0 & 21.8 & 20.6 \\
production (year) & 64.0 & 69.5 & 93.0 & 80.7 \\
Owned land (\%) & 33.5 & 25.9 & 7.0 & 17.5 \\
Rented land (\%) & 2.5 & 4.6 & 0.0 & 1.8 \\
Shared land (\%) & 71.8 & 74.6 & 79.9 & 76.8 \\
Irrigated land (\%) & 28.2 & 25.4 & 20.1 & 23.2 \\
Non-irrigated land (\%) & 35.4 & 38.7 & 69.8 & 48.2 \\
Fennel land (\%)* & & & & \\
Gross production value of fennel & 20.6 & 47.4 & 84.7 & 61.0 \\
production (\%) & 93.6 & 93.6 & 95.0 & 94.1 \\
Agricultural production value $(\%)$ & 9
\end{tabular}

When cost (expense) was mentioned in agricultural production, monetary value of the sources needed to be consumed for the production of a certain product (in other words, the monetary value of goods and services). In general, costs were covered with the gross production value obtained in a production period and the economy of activities carried out was presented. Production costs provide important information in terms of determining the source demand of production activities, source usage activity, cost and making planning and policy [8]. Production costs per hectare in fennel production were 3779.3 TL and change from 3639.3 to $4879.0 \mathrm{TL}$ in farms groups. There was a statistical difference between this cost element and farms groups. In other words, if the fennel area in farms increases, the production costs per unit area decrease. Variable cost elements constitute the most important component of production costs. Seed which is used in fennel production, decreases and increases depending on the population of these activities, fertilizer, pesticide, irrigation, temporary labour, machine rent and other variable costs constitute variable costs. Variable costs constitute $65.7 \%$ of production costs. Variable cost per hectare in farms groups changes between $2397.2 \mathrm{TL}$ and $3274.4 \mathrm{TL}$. It was $2483.8 \mathrm{TL}$ in farms average. Variable costs per hectare in farms groups were showed difference statistically. Fixed costs in fennel production consist of general 
administration expenses, land tenure and family labour costs. Fixed costs constitute $34.3 \%$ of total productions costs.

Fixed costs per hectare were 1295.5 TL and it was decreased as the fennel area in the farms increases. When cost components per hectare in fennel production of farms in the region were analysed, it was seen that land tenure was the most important cost element. This cost element was 1010.9 TL per hectare. It was constituted $26.7 \%$ of production costs. This cost element was followed by machine rent cost with a share of $19.4 \%$.

Machine rent cost was 731.6 TL per hectare. The third important cost component was irrigation. Irrigation was constituted $11.5 \%$ of total production costs. Irrigation costs were calculated as $433.1 \mathrm{TL}$ per hectare. Temporary labour was amounted as 375.6 TL, pesticide cost was 311.8 TL, fertilizer cost was 258.6 TL, other variable costs were $219.2 \mathrm{TL}$, family labour was 210.1 TL, interest of working capital was $118.3 \mathrm{TL}$, general administration costs were 74.5 TL and seed cost was 35.5 TL per hectare respectively. It was identified that there was a statistical difference between enterprise groups about these costs (Table 3).

TABLE 3: PRODUCTION COST PER HECTARE OF FENNEL PRODUCTION

\begin{tabular}{|c|c|c|c|c|}
\hline \multirow{2}{*}{ Indicator } & \multicolumn{3}{|c|}{ Groups of farms } & \multirow{2}{*}{ Average } \\
\hline & I & II & III & \\
\hline & \multicolumn{4}{|c|}{ Production cost per hectare (TL) } \\
\hline Seed $^{*}$ & 53.4 & 40.0 & 32.5 & 35.5 \\
\hline Fertilization & 371.3 & 283.6 & 240.1 & 258.6 \\
\hline Pesticide & 378.7 & 300.8 & 307.5 & 311.8 \\
\hline Irrigation & 599.9 & 459.4 & 408.6 & 433.1 \\
\hline Labour & 370.0 & 304.4 & 394.5 & 375.6 \\
\hline Renting cost of machinery* & 1142.4 & 760.1 & 680.4 & 731.6 \\
\hline Other variable cost & 202.8 & 225.3 & 219.4 & 219.2 \\
\hline Interest of working capi.* & 155.9 & 118.7 & 114.2 & 118.3 \\
\hline Variable cost* & 3274.4 & 2492.3 & 2397.2 & 2483.8 \\
\hline General administ. expenses & 98.2 & 74.8 & 71.9 & 74.5 \\
\hline Land tenure & 835.7 & 942.3 & 1047.2 & 1010.9 \\
\hline Family labour & 670.7 & 358.2 & 122.9 & 210.1 \\
\hline Fixed cost & 1604.6 & 1375.2 & 1242.0 & 1295.5 \\
\hline \multirow[t]{2}{*}{ Total production cost* } & 4879.0 & 3867.5 & 3639.3 & 3779.3 \\
\hline & \multicolumn{4}{|c|}{ Percentage $(\%)$} \\
\hline Seed $^{*}$ & 1.1 & 1.0 & 0.9 & 0.9 \\
\hline Fertilization & 7.6 & 7.3 & 6.6 & 6.8 \\
\hline Pesticide & 7.8 & 7.8 & 8.5 & 8.3 \\
\hline Irrigation & 12.3 & 11.9 & 11.2 & 11.5 \\
\hline Labour & 7.6 & 7.9 & 10.8 & 9.9 \\
\hline Renting cost of machinery* & 23.4 & 19.7 & 18.7 & 19.4 \\
\hline Other variable cost & 4.2 & 5.8 & 6.0 & 5.8 \\
\hline Interest of working cap.* & 3.2 & 3.1 & 3.1 & 3.1 \\
\hline Variable cost* & 67.1 & 64.4 & 65.9 & 65.7 \\
\hline General administ. expenses & 2.0 & 1.9 & 2.0 & 2.0 \\
\hline Land tenure & 17.1 & 24.4 & 28.8 & 26.7 \\
\hline Family labour & 13.7 & 9.3 & 3.4 & 5.6 \\
\hline Fixed cost & 32.9 & 35.6 & 34.1 & 34.3 \\
\hline Total production cost* & 100.0 & 100.0 & 100.0 & 100.0 \\
\hline
\end{tabular}

TL: Turkish Liras, (for 2013, 1 US dollars = 1.908291 TL

When labour and machine power amounts that farms use in fennel production were analysed, it was seen that there were more uses in small sized farms. This situation was also statistically important. Labour usage per hectare in fennel production was 94.6 hours and it was identified that the most usage was performed in hoeing (49.2\%) and harvest. Machine power usage was 15.9 hours per hectare. It was seen that machine power was mostly used in hoeing (19.6\%) and soil preparation $(42.5 \%)$ (Table 4$)$.

TABLE 4: USING LABOUR AND MACHINERY PER HECTARE IN FENNEL PRODUCTION

\begin{tabular}{|c|c|c|c|c|c|c|c|c|}
\hline \multirow{3}{*}{$\begin{array}{l}\text { Farming } \\
\text { activities }\end{array}$} & \multicolumn{8}{|c|}{ Groups of farm } \\
\hline & \multicolumn{4}{|c|}{ Using labour per hectare (hr) } & \multicolumn{4}{|c|}{ Using machinery per hectare (hr) } \\
\hline & I & II & III & Average & $\overline{\mathrm{I}}$ & II & III & Average \\
\hline $\begin{array}{l}\text { Soil } \\
\text { preparation }\end{array}$ & 16.4 & 8.4 & 6.3 & 7.5 & 12.5 & 7.9 & 5.9 & 6.8 \\
\hline Seedling & 15.2 & 9.6 & 5.5 & 7.0 & 3.2 & 1.2 & 1.1 & 1.3 \\
\hline Fertilization & 5.9 & 2.9 & 2.4 & 2.7 & 1.3 & 0.5 & 0.7 & 0.7 \\
\hline Irrigation & 14.4 & 10.6 & 9.6 & 10.2 & 0.3 & 0.2 & 0.2 & 0.2 \\
\hline Hoeing & 65.4 & 52.8 & 46.5 & 49.2 & 5.7 & 3.3 & 2.8 & 3.1 \\
\hline Pesticide & 1.0 & 0.9 & 1.0 & 1.0 & 0.5 & 0.5 & 0.5 & 0.5 \\
\hline Harvesting & 28.1 & 16.1 & 8.7 & 11.6 & 3.7 & 1.7 & 1.0 & 1.3 \\
\hline Milling & 14.0 & 4.9 & 3.4 & 4.5 & 2.3 & 1.8 & 1.5 & 1.6 \\
\hline Transportation & 1.6 & 1.0 & 0.6 & 0.8 & 0.9 & 0.6 & 0.3 & 0.4 \\
\hline \multirow[t]{2}{*}{ Total* } & 162.0 & 107.3 & 84.1 & 94.6 & 30.4 & 17.5 & 13.9 & 15.9 \\
\hline & \multicolumn{4}{|c|}{ Percentage $(\%)$} & \multicolumn{4}{|c|}{ Percentage $(\%)$} \\
\hline $\begin{array}{l}\text { Soil } \\
\text { preparation }\end{array}$ & 10.1 & 7.8 & 7.5 & 7.9 & 41.1 & 44.9 & 42.1 & 42.5 \\
\hline Seedling & 9.4 & 8.9 & 6.5 & 7.4 & 10.5 & 6.8 & 7.8 & 8.0 \\
\hline Fertilization & 3.6 & 2.7 & 2.8 & 2.9 & 4.3 & 2.7 & 4.7 & 4.2 \\
\hline Irrigation & 8.9 & 9.9 & 11.5 & 10.8 & 0.9 & 1.2 & 1.4 & 1.3 \\
\hline Hoeing & 40.4 & 49.2 & 55.3 & 52.0 & 18.9 & 18.6 & 20.1 & 19.6 \\
\hline Pesticide & 0.6 & 0.9 & 1.2 & 1.1 & 1.7 & 2.6 & 3.7 & 3.2 \\
\hline Harvesting & 17.3 & 15.0 & 10.3 & 12.3 & 12.0 & 9.5 & 7.3 & 8.5 \\
\hline Milling & 8.7 & 4.6 & 4.0 & 4.8 & 7.6 & 10.4 & 10.7 & 10.1 \\
\hline Transportation & 1.0 & 0.9 & 0.8 & 0.8 & 2.9 & 3.2 & 2.3 & 2.6 \\
\hline Total & 100.0 & 100.0 & 100.0 & 100.0 & 100.0 & 100.0 & 100.0 & 100.0 \\
\hline
\end{tabular}

Usage amounts of production input used in fennel production were given in Table 5. Chemical fertilizer amount was $131.8 \mathrm{~kg}$, animal manure was $918.7 \mathrm{~kg}$, foliar fertilizer was $280 \mathrm{gr}$, herbicide was $1671.3 \mathrm{gr}$, fungicide was $206.3 \mathrm{gr}$ and seed was 9157.3 gr that were used in fennel production per hectare. There was a statistical difference between foliar fertilizer usage amount and fennel cultivation area size. In other words, as the size of farm increases using less foliar fertilizer on the unit area was in question (Table5).

It was detected that chemical fertilizer and fungicide were less applied in group II farms. Animal manure, foliar fertilizer and herbicide usages were the least in group III farms per unit area.

TABLE 5: USING SEED, FERTILIZER AND PESTICIDE PER HECTARE IN FENNEL PRODUCTION

\begin{tabular}{lrrrrrr}
\hline \hline $\begin{array}{l}\text { Groups } \\
\text { of farm }\end{array}$ & $\begin{array}{r}\text { Chemica } \\
\text { 1 fer. }(\mathrm{kg})\end{array}$ & $\begin{array}{c}\text { Manur } \\
\mathrm{e}(\mathrm{kg})\end{array}$ & $\begin{array}{c}\text { Foliar } \\
\text { fert. } \\
(\mathrm{gr})^{*}\end{array}$ & $\begin{array}{c}\text { Herbicid } \\
\mathrm{e}(\mathrm{gr})\end{array}$ & $\begin{array}{c}\text { Fungicid } \\
\mathrm{e}(\mathrm{gr})\end{array}$ & \multicolumn{1}{c}{$\begin{array}{c}\text { Seed } \\
(\mathrm{gr})\end{array}$} \\
\hline \hline I & & & & & & 11502. \\
& 162.8 & 1468.1 & 876.6 & 1864.1 & 239.9 & 1 \\
\hline II & 128.9 & 1170.2 & 239.4 & 1845.0 & 197.5 & 9998.2 \\
\hline III & 129.2 & 795.5 & 226.7 & 1606.2 & 204.9 & 8691.5 \\
\hline \hline Average & 131.8 & 918.7 & 280.0 & 1671.3 & 206.3 & 9157.3 \\
\hline \hline
\end{tabular}

Gross production value was calculated by multiplying the product amount that farms obtained as a result of fennel production and the fennel prizes. Gross profit was obtained by subtracting variable costs from the gross production value. When profitability indicators of farms producing fennel were analysed, gross production value, gross profit and net profit were calculated as 7939.4 TL, 5455.6 TL and 4160.1 TL respectively.

Cost was the monetary expression of the date used for 
carrying out production [9]. In other words, it was the expense amount made for obtaining an economic value or cost price [10]. The basic aims of cost account were determining unit costs, lending assistance to enterprise activities, preparing productions plans and taking decisions regarding the enterprise $[11 ; 9 ; 12 ; 13]$. In this study, unit fennel production cost was obtained by dividing total production costs to fennel production amount. In the farms, $1 \mathrm{~kg}$ fennel production cost was $1.58 \mathrm{TL}$ and this costs vary between $1.38 \mathrm{TL}$ and $1.74 \mathrm{TL}$ in the farms groups.

Gross production value, gross profit, net profit and relative profit indicators were the highest in group III farms. Cost per kg production was the highest value in group I and the lowest value in group II farms (Table 6).

TABLE 6: PROFIT INDICATOR IN FENNEL PRODUCTION

\begin{tabular}{lccccc}
\hline \hline $\begin{array}{l}\text { Groups of } \\
\text { farm }\end{array}$ & $\begin{array}{c}\text { Gross } \\
\text { production } \\
\text { value per } \\
\text { hectare } \\
\text { (TL) }\end{array}$ & $\begin{array}{c}\text { Gross } \\
\text { margin per } \\
\text { hectare } \\
\text { (TL) }\end{array}$ & $\begin{array}{c}\text { Net profit } \\
\text { per hectare } \\
\text { (TL) }\end{array}$ & $\begin{array}{c}\text { Relative } \\
\text { profit }\end{array}$ & $\begin{array}{c}\text { Per kg } \\
\text { production } \\
\text { cost (TL) }\end{array}$ \\
\hline I & 7952.2 & 4677.8 & 3073.2 & 1.63 & 1.74 \\
II & 7834.5 & 5342.2 & 3967.0 & 2.03 & 1.38 \\
III & 7965.0 & 5567.7 & 4325.7 & 2.19 & 1.57 \\
\hline \hline Average & 7939.4 & 5455.6 & 4160.1 & 2.10 & 1.58 \\
\hline \hline
\end{tabular}

Among the interviewed farms, $25.9 \%$ of them were carrying out livestock activities, and they had differences regarding the age of the enterprise, property area and rented area. They were younger (53.9 years), had less property area (35.9 hectare) and rented more land for cultivation ( 24.85 hectare). It was determined that the use of labour and machine power per unit area was more in farms which give place to livestock production activity within their agricultural activities. These indicators were statistically important.

About $21 \%$ of interviewed farms had non-agricultural income. For these producers, education level of enterprise owners, fallow area and the share of agriculture in total incomes showed difference. In these farms education levels of farms managers were higher (7.4 years), fallow area was more (8.6 hectare) and the share of agriculture in total incomes was lower $(\% 72.1)$.

It was observed that gross profit (6310 TL), absolute profit (5034 TL) and relative profit (2.4) and the use of chemical fertilizer $(210 \mathrm{~kg})$ were higher among those fennel producers who use computers. Their education levels were also high (7.7 years). It was also seen that farms managers using computer were younger (49.9 years), their production costs (3782 TL), machine renting cost $(589.8 \mathrm{TL})$ and bollard pull use amounts (15.5 hours) were lower.

It was observed that machine renting cost, fixed cost, age, education level and bollard pull uses were statistically different in fennel producers who use internet $(6.2 \%)$. It was found out that farms managers using internet were younger (46.0 years), their education levels were higher (8.6 years) and their fixed costs (1063 TL) and machine renting costs (504 TL) were lower. Bollard pull uses of these enterprises were also lower (13 hours).

There were statistical differences in land renting costs and chemical fertilizer uses of fennel producing enterprises who read newspaper $(30.9 \%)$ were higher. In these farms, land renting costs were lower (841 TL) and chemical fertilizer uses were higher $(196 \mathrm{~kg})$.

It was found that pesticide costs were higher (358 TL) and fennel areas were smaller ( 0.4 hectare) in fennel producing farms which were members of an organization (61.7\%). It was also identified that member farms carry out fennel production activities for a shorter time (18.6 years) and their fungicide use amounts $(251 \mathrm{gr})$ and the share of fennel in total gross production value was higher $(46.9 \%)$.

It was observed that land rent costs (869 TL) of farms barrowing loans $(61.7 \%)$ were lower. It was also seen that farms using loan carried out fennel production activities for a shorter time (18.6 years).

The results indicated that labour use of farms $(49.4 \%)$ receiving government support was lower (117 hours). Their total agricultural lands were more (8.82 hectare) and the share of fennel in total gross production value was higher $(57.6 \%)$. Farms receiving government support had more owned land (7.92 hectare).

Gross profit (6001 TL) and absolute profit (4642 TL) values of enterprises carrying out contracted production activities of fennel production were also higher. Relative profit (2.2) values were also high. Education levels of those were high (7.5 years). Machine renting costs of those farms were lower (780 TL). The share of agriculture in total incomes of those farms was higher $(88.8 \%)$.

\section{CONCLUSION}

Fennel production area in enterprises constitutes $48.2 \%$ of the total enterprise area. Approximately half of the total gross production value of enterprises was obtained from fennel production. Gross production value obtained from fennel production was calculated as 7939.4 TL. Relative profit was calculated as 2.10. While the price formation of fennel occurs in free market conditions the change in prices will affect the incomes of the producers significantly. Price fluctuations could be moderately, thus reducing fluctuations of growers' income.

\section{ACKNOWLEDGMENT}

We would like to thank to TÜBİTAK (2209) and Süleyman Demirel University BAP (Scientific Research Projects Coordination Unit) for their diverse support for this study.

\section{REFERENCES}

[1] Başer, K.H.C., "Tıbbi ve aromatik bitkilerin ilaç ve alkollü içki sanayiinde kullanımı". İstanbul Ticaret Odası Yayın No: 1997-39, İstanbul, 1997.

[2] Davis, P.H., "Flora of Turkey and the east agean islands". Labiatae, University Press, Edinburg Volume 7: 462-463, 1982.

[3] Ceylan, A., "Tibbi Bitkiler II (Uçucu Yağ Bitkileri)". Ege Üniv. Ziraat Fak. Yayını No:481, İzmir, 1997.

[4] Baydar, H. "Tibbi ve aromatik ve keyf bitkileri bilimi ve teknolojisi". Süleyman Demirel Üniversitesi Ziraat Fakültesi SDÜ Yayın No: 51, 154 p. 2005.

[5] Uzun, A., Kevseroğlu, K., Özçelik, H., and Yılmaz, S., "Determination of some agricultural traits of coriander (Foeniculum vulgare Mill. var. Dulce) lines developed for the middle Black-Sea Region of Turkey and stability analysis on the yield and quality traits (Turkish)". Anadolu J. Agr. Sci., 27(1):23-30, 2012. 
https://doi.org/10.7161/anajas.2012.v27n1.2330

[6] Guil Guerrero, J.L.,Campra Madrid, P., and TorijaIsasa, M.E., "Mineral elements determination in wild edible plants". Ecology of Food and Nutrition, 38(3): 209-222, 1999

https://doi.org/10.1080/03670244.1999.9991578

[7] Edinçliler, N., "Ege bölgesinde sebze olarak değerlendirilen yabancı otlar ve besin değerleri”. Ege Üniversitesi Fen Bilimleri Enstitüsü Yüksek Lisans Semineri,İzmir, 2000.

[8] Kıral, T., Kasnakoğlu, H., Tatlıdil, F.F., Fidan, H., and Gündoğmuş, E., "Tarımsal Ürünler İçin Maliyet Hesaplama Metodolojisi ve Veritabanı Rehberi”. Tarımsal Ekonomi Araştırma Enstitüsü Yayınları, Proje Raporu 1999-13, 143s., Ankara, 1999.

[9] Açı1, A.F., "Tarımsal Ürün Maliyetlerinin Hesaplanması ve Memleketimiz Tarımsal Ürün Maliyetlerindeki Gelișmeler". A.Ü.Z.F. Yayınları: 665, Bilimsel Araştırma ve İncelemeler: 91, Şark Matbaası, 77 p., Ankara, 1977.

[10] Backer, M. and Jacobsen, L.E., "Yönetim açısından maliyet muhasebesi 2.Baskı", (Çeviren:Sadık Baklacıŏglu). Beta Basım Yayım, İstanbul, 1983.

[11] Kıral, T., "Ziraat işletmelerinde defter tutumu şekilleri ve mukayesesi". T.C. Ankara Üniversitesi Ziraat Fakültesi Tarım Ekonomisi Bölümü (Basılmamıs Doktora tezi), Ankara, 1970.

[12] Aras, A., "Tarım muhasebesi". T.C. Ege Üniversitesi Ziraat Fakültesi Yayınları, No: 486, 323p., Bornova, İzmir, 1988.

[13] Bursal, N. and Ercan,Y., "Maliyet muhasebesi ilkeler ve uygulama". Der Yayınları, 4. Basım, İstanbul, 1992.

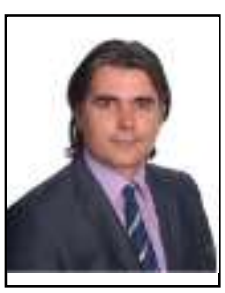

Scientific CV (optional)

Assoc. Prof. Dr. MEVLÜT GÜL

Department of Agriculture Economics,

Faculty of Agriculture,

Süleyman Demirel University

32260 Isparta-TURKEY

Telephone +902462118588

Mobile. +905326969701

E-mail : mevlutgul@sdu.edu.tr

Web : https://w3.sdu.edu.tr/personel/01448/doc-dr-mevlut-gul Specialised on

1. Agricultural economics

2. Production economics

3. Farm management

4. Agricultural marketing

Some publications

GUL, M., AKPINAR, M.G., 2012. An Assessment of Factors Affecting Packaged Water Consumption Decisions of the Households, International Journal of Food, Agriculture, and Environment (JFAE), 10, 252-257

AKPINAR, M.G., GUL, M., GULCAN, S., 2013. Evaluation of the Factors Affecting Water Saving Attitudes of Urban Life towards the Next Century. Global Business and Technology Association's Fifteenth Annual International Conference July 2nd - 6th, 2013, Helsinki, Finland.

AKPINAR, M.G., GUL, M., 2014. An assessment of consumer preferences on the drinking water market: today to the future, Journal of Water Supply Research and Technology-AQUA, 63, 525-531.

AKPINAR, M.G., GUL, M., GULCAN, S., 2014. Sensitivity on Drinking Water Safety and Affecting Factors for Urban Society. International Academic Conference, "Education Culture and Society 2014, 15th - 18th, September, Wroclaw-Poland. 